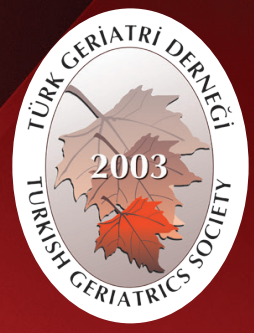

Turkish Journal of Geriatrics

DOI: $10.31086 /$ tjgeri.2018240420

2018;21 (2):193-205

Şebnem BEŞE CANPOLAT ${ }^{1}$

\title{
CHANGES IN THE HOUSEHOLD STRUCTURES OF THE ELDERLY: HOUSEHOLD PROJECTIONS FOR TURKEY, 2016-2050
}

\section{Abstract}

Introduction: The main objective of this study was to analyze the current household patterns of the elderly in Turkey and project in what kinds of households the elderly will live in the future.

Materials and Method: The household structure of the elderly population was analyzed using tabulated data from Turkey's Address-Based Population Registration System, for the first time ever. Household projections were produced according to the headship rate method.

Results: The percentage of households with elderly persons will continuously increase, from $22.5 \%$ in 2016 to approximately $41 \%$ in 2050 . The presence of elderly in all household types will continuously increase during that period, except extended-family households. While in 2016 9.9\% of nuclear families lived with at least one elderly person, by 2050 this percentage will have risen to $19.6 \%$. One-person elderly households will also continuously increase, from $5.4 \%$ in 2016 to $14.7 \%$ in 2050 .

Conclusion: The elderly population in Turkey will mostly live in one-family households in the future, as is the case at present, but there will be an increase in the number of elderly living in one-person households. In 2050, about $15 \%$ of all households in Turkey will be oneperson elderly households. The elderly will steadily move from co-residence lifestyles to single-resident lifestyles. The views expressed in this paper are those of the author and do not necessarily represent the official views of the Turkish Statistical Institute.

Keywords: Aged; Family characteristics; Demography; Life style

CORRESPONDANCE

Şebnem BEŞE CANPOLAT

Turkish Statistical Institute, Head of Demographic Statistics Department, Ankara, Turkey

Phone: 3122405215

e-mail: sebnemcanpolat@gmail.com

Received: 25/12/2017

Accepted: $17 / 04 / 2018$

Turkish Statistical Institute, Head of Demographic Statistics Department, Ankara, Turkey

\section{YAŞLI BIREYLERIN HANEHALKI YAPISINDAKI DEĞIŞiM: TÜRKIYE IÇiN HANEHALKI PROJEKSIYONLARI, 2016-2050}

\section{$\ddot{O}_{z}$}

Giriş: Bu çalışmanın temel amacı Türkiye'de yaşlı nüfusun günümüzde yaşadığı hane halkı yapısının tespit edilmesi ve bu yapı ve değişimden yola çıkarak gelecekte yaşlı bireylerin ne tip hane halkı kompozisyonlarında yaşayacaklarının tespit edilmesi amacıyla hane halkı projeksiyonlarının üretilmesidir.

Gereç ve Yöntem: Yaşlı nüfusun hane halkı yapısı, Adrese Dayalı Nüfus Kayıt Sisteminin sonuçları kullanılarak ilk kez analiz edildi ve hane halkı projeksiyonları, hane halkı reisliği hızı yöntemi kullanılarak üretildi.

Bulgular: 2016 yılında \%22.5 olan yaşlı birey içeren hane halkı oranı 2050 yılında sürekli bir artış ile \% 41 'e ulaşacaktır. Hane halkı türündeki değişimi incelediğimizde, yaşlı hane halkları, 2016-2050 döneminde geniş-aile hane halkı tipi dışındaki tüm hane halkı türlerinde sürekli artmaktadır. En az bir yaşlı birey içeren çekirdek aile oranı 2016 yılında \%9.9 iken bu oran 2050 yılında \%19.6 olacaktır. Tek kişilik yaşlı hane halkı oranı da benzer şekilde sürekli bir artış göstererek 2016-2050 döneminde \%5.4'ten \%14.7'ye ulaşacaktır.

Sonuç: Yaşlılar Türkiye'de bugün olduğu gibi gelecekte de büyük oranda çekirdek hanelerde yaşayacak ve tek kişilik hane halklarında yaşayan yaşlı nüfus oranında da bir artış meydana gelecektir. 2050 yılında Türkiye'deki toplam hane halkının yaklaşık \%15'i tek kişilik yaşlı hane halklarından oluşacaktır. Sonuç olarak, Türkiye'de yaşlıların birlikte yaşam biçiminden tek başına yaşam biçimine geçme eğilimde oldukları görülmektedir. Çalışmada ifade edilen görüşler tamamen yazara ait olup Türkiye İstatistik Kurumunu bağlamaz.

Anahtar sözcükler: Yaşlı; Aile özellikleri; Demografi; Yaşam tarzı 


\section{INTRODUCTION}

One of the important demographic changes that characterize the early decades of the $21^{\text {st }}$ century is the increasing aging of the human population. Both the number and proportion of people aged 65 years and older are growing, although at different rates in different parts of the world.

Turkey is undergoing a demographic transformation, like many parts of the world. Even though the proportion of elderly in Turkey is small, and other indicators of aging suggest that the age structure of Turkey is still relatively young when compared with the populations of developed countries, the increase in the elderly population in absolute numbers is significant, and the number of older adults is equal to the total populations of some small European countries. One of the major reasons for the aging of the Turkish population is the continuous decline in the total fertility rate, which is also being observed in developed countries. Another reason is the increase in longevity due to the declining mortality rate. In Turkey, life expectancy at birth is 78 years; 75.3 years for men and 80.7 years for women, according to the Turkish Statistical Institute (TurkStat) 2016 Life Table. If the current trends of demographic indicators persist, the Turkish population will continue aging. While the proportion of elderly in the total population was $7.7 \%$ in 2013, it reached $8.5 \%$ in 2017, and is expected to reach $10.2 \%$ in 2023 (1).

Due to the continuously increasing elderly proportion, it is necessary to examine the elderly's needs and concerns to understand how to care for them. The changes in the proportion of the older population, and its size, have profound implications for families. As the population gets older, in society the family performs the function of a buffer that aims to decrease the social and economic impact of population aging. In particular, demographic aging changes both household structure and household size.
In most developing countries, it is assumed that family, as an informal care institution, will continue their traditional role of taking care of the elderly. This approach or view causes the states in those countries to be inactive toward aging issues. Similarly, in Turkey, it is often assumed that households' members or relatives will automatically take on the responsibility of caring for the elderly. However, the traditional family is changing due to modernization, industrialization, and individualism $(2,3)$. Even if there are still strong family ties in Turkey, this familial solidarity is affected by social, economic and demographic changes due to especially transformation from an agricultural to an industrial society and urbanization. Parent-child coresidence is not a norm in contemporary Turkey and adult children prefer to live nearby older family members and to have privacy while maintaining close family ties. Individuals in metropolitan areas might exchange with having "intimacy at a distance" by living nearby. From this perspective, nuclear families can be interpreted as acting functionally extended families (4-6).

In Turkey, the proportion of elders who want to coresidence with his/her children was $40.2 \%$, the proportion of elders desiring to get home care service was $38.6 \%$ and the proportion of elders desiring to go nursing home was $7.7 \%$ according to the Family Structure Survey in 2016. The most important reason for desiring to stay in the nursing home of elderly individuals was that they do not want to be a burden on his/her children with $48.9 \%$. The second important reason was that facilities in nursing home are more comfortable with $20.2 \%$ and the third important reason was that his/her children might not like to coresidence with them with $11.2 \%(7)$.

The Ministry of Family and Social Policy is the central institution for proposing, adopting, coordinating and improving social policies regarding older people at national level in 


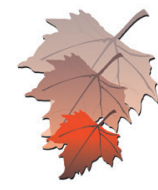

Turkey. In the "2017-2020 Active Aging Strategy Document" by the Ministry, the policies on aging were proposed mainly in the field of care and rehabilitation services. According to the records of the Ministry, in accordance with the Law No. 2022 on the "Providing Old-Age Assistance to Poor, Weakness and Homeless Turkish Republic People who Completed 65 Years Old" the number of beneficiaries who were found to be in need was 620.019, while the proportion was $9.3 \%$ in total elderly population in 2016 (7). Although this law seems to provide social protection to elderly, many of old persons cannot reach these salaries and other economical supports due to bureaucratic formalities. The average annual amount of benefit made per the elderly was 2 thousand $548 \mathrm{TL}$. This amount of salary is not too enough to provide a decent live for the elderly (8).

In 2017, the proportion of old people residing in institutional places is $0.4 \%$ in Turkey. This proportion shows us the insufficiency of the number of care facilities to meet the institutional care needs of old people. Due to inadequate formal care services, the unsatisfactory informal caring services have expanded continuously. It is obvious that the number of the older people grows rapidly in Turkey, elderly care needs will increase in the future. Therefore, the policies regarding old people institutional and especially home-based care in Turkey need to be adopted to provide decent lives for the elderly $(8,9)$.

In the light of above mentioned facts, the main objective of this study was to analyze current household patterns in Turkey and project in what kinds of households older-aged people will live in the future, using tabulated data from Turkey's Address-Based Population Registration System (ABPRS). This study produced household projections for the 2020-2050 period, using the extrapolative headship rate household projection method.

\section{MATERIALS AND METHOD}

The main tabulated data on family and household typologies used by this study related to household types and were produced by TurkStat using information from Turkey's Central Civil Registration System and ABPRS for the years 2014, 2015, and 2016 (Table 1). Tabulated data was obtained by official data request to TurkStat Data Dissemination Group. For the first time, in May 2016, TurkStat produced and published statistics on household types, officially based on the administrative registers for both the country and its provinces.

These definitions and classifications of household types were adopted in line with international standards. "Household" refers to a person living alone, or a group of persons living at the same address, with or without any kind of kinship. The concept of "household-dwelling" was used as the method.

Headship rates were projected for four household types: one-person households, onefamily (nuclear) households, extended-family households, and multi-person households without nuclear families. "One-person household" means a household that consists of a person living alone. Types of "nuclear families" can be grouped as follows: couples without resident children, couples with at least one resident child, and lone parents with at least one resident child. While "extended-family households" cover multi-family households, or at least one nuclear family with non-family member(s), "multi-person households without nuclear families" cover households whose members are not related to each other, as couples or as parent and child.

Generally, household and family projections are used to plan housing and building, the development of public utilities, and the production and distribution of consumer durables for which the units of consumption are households rather than individuals. Specifically, some concern has been 
centered on the future growth of the number of families, the number of married couples, and the distribution of families by type (nuclear, patriarchal, etc.).

Although several types of household projection models have been developed over the past few decades (10), most existing household forecasts are based on a headship rate approach (static macro-demographic models). If basic population projections by sex and age are adequate, these can provide a reasonably accurate picture of the future number and composition of households. However, this method cannot take into account the dynamic aspects of household formation, growth, contraction, and dissolution $(11,12)$.

There are some methodological advantages to the headship rate method of household projections over other methods. The headship rate method is based on the assumption that the number of households is equivalent to the number of heads of households (13):

$$
h(\mathrm{i}, \mathrm{j}, \mathrm{t})=\frac{\mathrm{H}(\mathrm{i}, \mathrm{j}, \mathrm{t})}{\mathrm{P}(\mathrm{i}, \mathrm{j}, \mathrm{t})} \quad(\text { Equation } 1)
$$

The formula for projecting the number of households may be presented as follows. Suppose that for year $t+x$ ( $x$ years from the base year), population projections by sex and age have already been prepared, and the (sex) - age headship rates
(Number of households)=(number of heads of households) $=($ total population) * (headship rate)

The initial number of households and populations were categorized by head of household age. In this study, the oldest member of the household was assumed to be the head of the household. Studies have shown that the oldest member of the family, irrespective of their sex, is commonly declared the head of the household. Age is an important determining factor when declaring a household's head in Turkey.

To clarify the headship rate method, it may be useful to express the steps using an algebraic equation. Let $P(i, j, t)$ be the population of sex $i$ and age $j$ at time $t$, and let $H(i, j, t)$ be the number of heads of households or families by sex $i$, age $j$, and time $t$. Then, the headship rate specific for sex and age, at time $t, h(i, j, t)$ is expressed using the following formula:

have been prepared using Equation 1, and the headship rates by age have been estimated, then the number of households for the year $t+x$ can be obtained using the following equation:

Total number of future households in year $\mathrm{t}+\mathrm{x}$

$\sum_{i} \sum_{j} H(i, j, t+x)=\sum_{i} \sum_{j} P(i, j, t+x) \times h(i, j, t+x) \quad$ (Equation 2)

In this study, an extrapolative method was used to produce household and family projections.

$$
h(i, j, t+x)=1-\lceil 1-h(i, j, t-n)\rceil \times\left[\frac{1-h(i, j, t)}{1-h(i, j, t-n)}\right]^{\frac{(t+x)-(t-n)}{n}} \quad \text { (Equation 3) }
$$

This method implies that headship rates in all age groups will continue to rise indefinitely but at a gradually diminishing pace. In some cases, it is possible to observe certain age groups showing decreases. However, the application of that formula to these age groups yields decreases in headship 
rates at a rather accelerating pace, which is clearly in opposition to the purpose of this study. Accordingly, for these age groups, the following formula is used:

$$
h(i, j, t+x)=h(i, j, t-n)\left[\frac{h(i, j, t)}{h(i, j, t-n)}\right]^{\frac{[(t+x)-(t-n)]}{n}} \quad \text { (Equation 4) }
$$

Non-institutional population projections are required to make household/family projections. To make a non-institutional population projection, a total of more than 15 non-institutional populations included in the "Household Labor Force Statistics" published by TurkStat and the age distributions of the non-institutional populations obtained for the purposes of the author's PhD thesis calculations were used.

\section{RESULTS}

Four main family types were organized under subheadings, and these subheadings were analyzed as to whether they included individuals 65 years of age and over.

According to 2016 ABPRS data, while the proportion of one-family households in Turkey was $67.4 \%$ in 2014 , one-family households comprised 66.4\% of all households in Turkey in 2016. Extended-family households, which cover multifamily households or at least one nuclear family with non-family member(s), comprised $16.3 \%$ of all households in 2016. The proportions of one-person households and multi-person households without nuclear families were $14.9 \%$ and $2.4 \%$, respectively, in 2016 (Table 1).

Table 1. Household types in Turkey, including elderly persons.

\begin{tabular}{|c|c|c|c|c|c|c|c|c|c|}
\hline \multirow[b]{2}{*}{ Type of households } & \multicolumn{3}{|c|}{$\begin{array}{l}\text { Households } \\
\text { without elderly }\end{array}$} & \multicolumn{3}{|c|}{$\begin{array}{l}\text { Households } \\
\text { with elderly }\end{array}$} & \multicolumn{3}{|c|}{ Total } \\
\hline & 2014 & 2015 & 2016 & 2014 & 2015 & 2016 & 2014 & 2015 & 2016 \\
\hline Oneperson households & 8.8 & 9.1 & 9.6 & 5.1 & 5.3 & 5.4 & 13.9 & 14.4 & 14.9 \\
\hline Onefamily household nuclear family) & 57.8 & 57.1 & 56.5 & 9.6 & 9.9 & 9.9 & 67.4 & 66.9 & 66.4 \\
\hline Extende family households & 9.6 & 9.6 & 9.5 & 7.1 & 6.9 & 6.7 & 16.7 & 16.5 & 16.3 \\
\hline Multi-person households without nuclear familie & 1.7 & 1.8 & 1.9 & 0.4 & 0.4 & 0.5 & 2.1 & 2.2 & 2.4 \\
\hline Total & 77.9 & 77.5 & 77.5 & 22.1 & 22.5 & 22.5 & 100.0 & 100.0 & 100.0 \\
\hline
\end{tabular}

Source: TurkStat; Available from http://www.tuik.gov.tr/PreHaberBultenleri.do?id=24646 and http://www.tuik.gov.tr/PreHaberBultenleri.do?id=24644 Accessed:12.09.2017.

There was at least one elderly person in $22.5 \%$ of all households in Turkey in 2016 (Table 1). In other words, one of every five households in Turkey included at least one elderly person. While $6.7 \%$ of households with elderly persons in 2016 were extended-family households, $9.9 \%$ of one-family (nuclear) households had elderly persons. The third type of household in which elderly persons lived was the one-person elderly household, type take place with a percentage of $5.4 \%$. 
While the above-mentioned rates were computed, two separate formulas exclusive to increases and decreases were utilized, to consider the variations in the years 2014-2016 (Annex 1). By using these computed headship rates and non-institutional population distributions, the distribution of household numbers was obtained (Table 3).
The household type percentages obtained using the headship rate extrapolative method are summarized in Table 2. According to the results of this study, the percentage of households with elderly persons will continuously increase, from $22.5 \%$ in 2016 to approximately $41.0 \%$ in 2050 (Table 2 and Figure 2). In Turkey, four of every ten households will be "elderly households" in 2050, based on current demographic conditions.

Table 2. Projected percentages of household types by year.

\begin{tabular}{|c|c|c|c|c|c|c|c|c|c|c|}
\hline \multirow[b]{2}{*}{ Years } & \multicolumn{2}{|c|}{$\begin{array}{l}\text { One-person } \\
\text { households } \\
-\overline{\text { with }}-\overline{\text { without }}\end{array}$} & \multicolumn{2}{|c|}{$\begin{array}{l}\text { One-family households } \\
\text { (nuclear family) }\end{array}$} & \multicolumn{2}{|c|}{$\begin{array}{l}\text { Extended-family } \\
\text { households }\end{array}$} & \multicolumn{2}{|c|}{$\begin{array}{l}\text { Multi-person } \\
\text { households without } \\
\text { nuclear families }\end{array}$} & \multicolumn{2}{|c|}{$\begin{array}{c}\text { Total } \\
\text { households } \\
\text { with without }\end{array}$} \\
\hline & elderly & elderly & elderly & elderly & elderly & elderly & elderly & elderly & elderly & elderly \\
\hline 2016 & 5,4 & 9,6 & 9,9 & 56,5 & 6,7 & 9,5 & 0,5 & 1,9 & 22,5 & 77,5 \\
\hline 2020 & 6,1 & 11,0 & 11,1 & 53,2 & 6,4 & 9,1 & 0,6 & 2,5 & 24,2 & 75,8 \\
\hline 2025 & 7,2 & 12,5 & 12,3 & 49,5 & 5,8 & 8,7 & 0,9 & 3,1 & 26,2 & 73,8 \\
\hline 2030 & 8,6 & 13,5 & 14,0 & 45,4 & 5,5 & 8,1 & 1,1 & 3,6 & 29,3 & 70,7 \\
\hline 2035 & 9,9 & 14,6 & 15,0 & 42,2 & 5,0 & 7,7 & 1,4 & 4,1 & 31,4 & 68,6 \\
\hline 2040 & 11,5 & 15,3 & 16,5 & 38,8 & 4,7 & 7,2 & 1,7 & 4,5 & 34,3 & 65,7 \\
\hline 2045 & 13,1 & 15,7 & 18,1 & 35,4 & 4,3 & 6,6 & 2,1 & 4,7 & 37,6 & 62,4 \\
\hline 2050 & 14,7 & 15,9 & 19,6 & 32,4 & 3,9 & 6,2 & 2,4 & 5,0 & 40,6 & 59,4 \\
\hline
\end{tabular}

While a share of nuclear family and extendedfamily households show a continuous decline, a continuous increase in one-person and multi-person households will be observed during the 2016-2050 period (Figure 1). The percentages of extendedfamily and nuclear family households will decrease to $10 \%$ and $52 \%$, respectively, in 2050 . According to the results of the projections, the percentage of one-person households will reach $30.6 \%$ in 2050, a two-fold increase over a 35-year period (Table 2 and Figure 1).

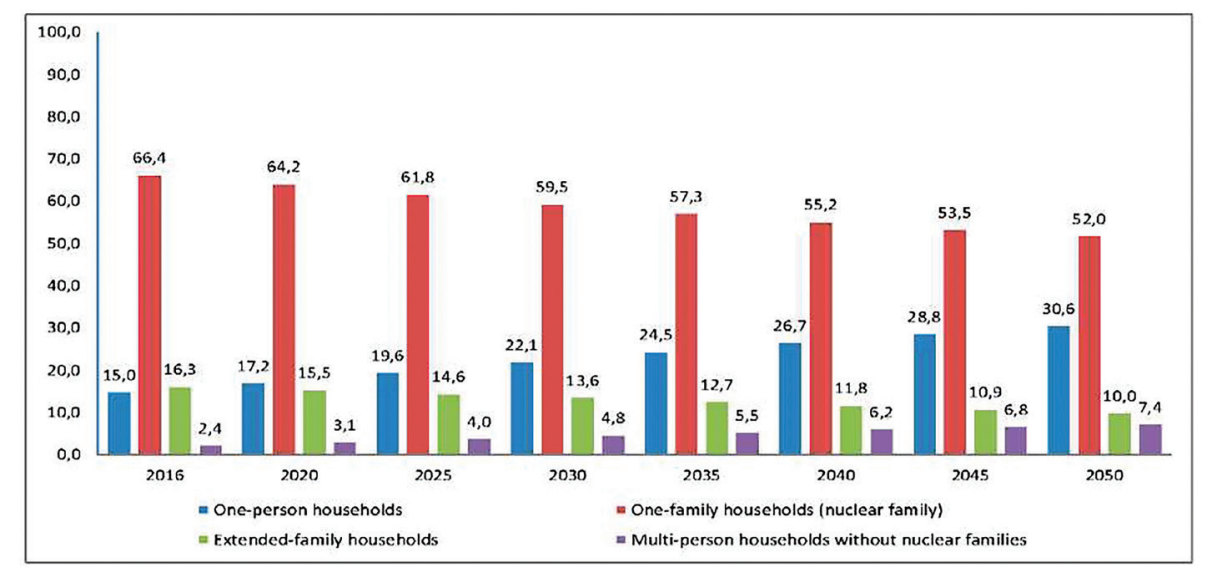

Figure 1. Percentage distributions of household types in Turkey, 2016-2050. 
When household types with elderly persons are considered (Table 2 and Figure 2), households that include at least one elderly person will continuously increase during the 2016-2050 period, across all household types, except extended-family households. While the percentage of nuclear families with at least one elderly person was $9.9 \%$ in 2016, this percentage will be about $19.6 \%$ in 2050. One-person elderly households will also continuously increase during the 2016-2050 period, from $5.4 \%$ to $14.7 \%$. The percentage of extendedfamily households with elderly persons will decrease, from $6.7 \%$ in 2016 to $3.9 \%$ in 2050.

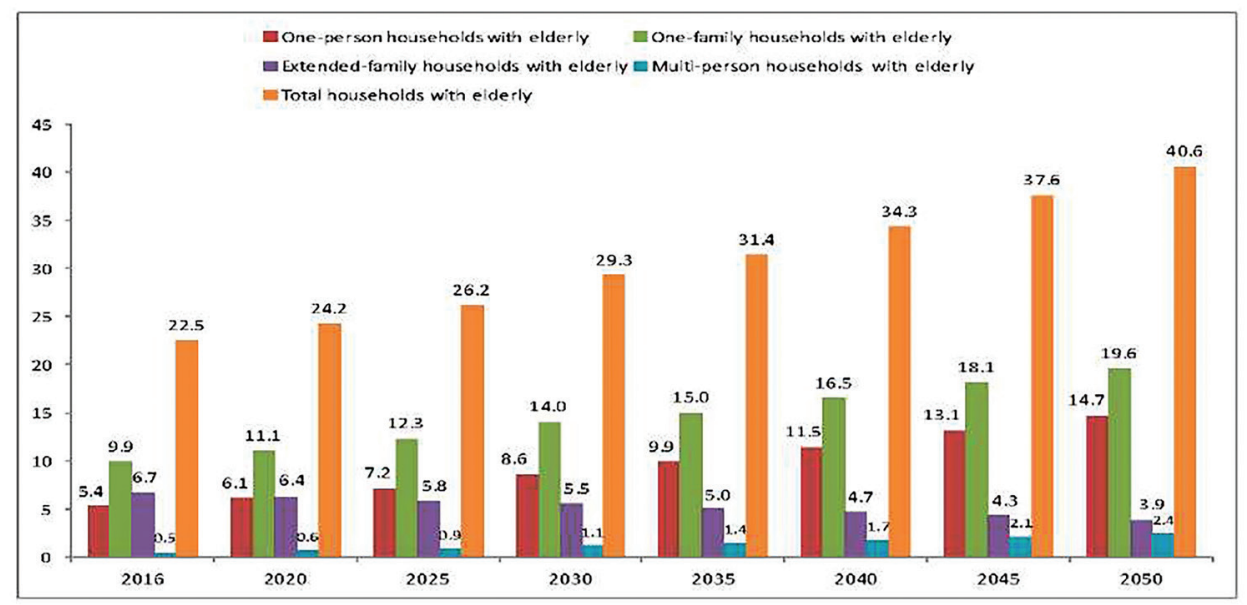

Figure 2. Percentage distributions of elderly households, 2016-2050.

Figure 3 shows the changes in household numbers during the 2016-2050 periods. According to the results of this study, the number of households in Turkey will approximately double between
2016 and 2050 -from 22 million to 41 million- and household growth will outpace population growth during every decade within this period.

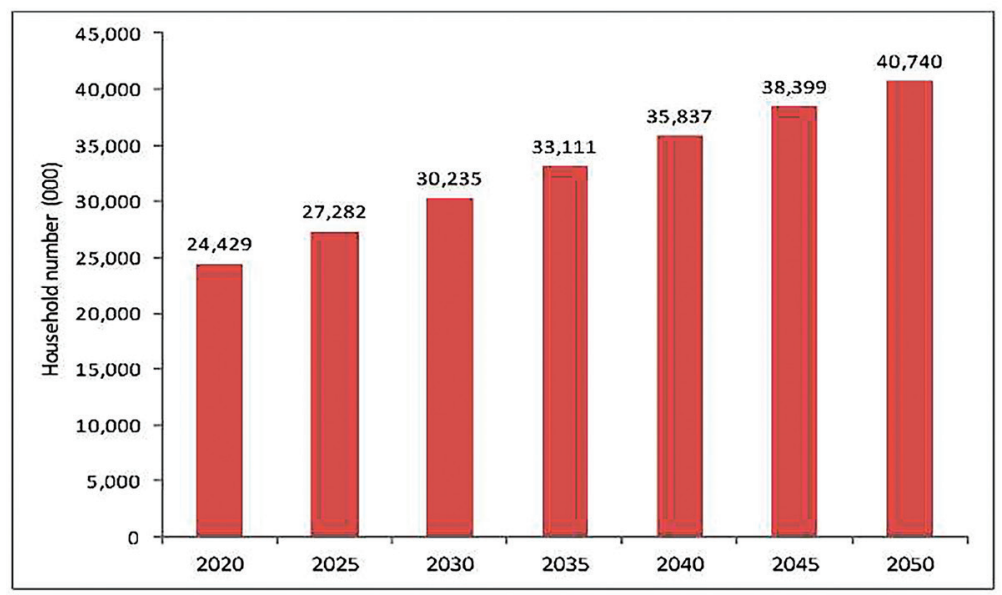

Figure 3. Projected household numbers in Turkey, 2020-2050. 
Despite continuous increases in both the number of households and the number of people in Turkey, it can be observed that the average household size has decreased from 5.7 persons in 1955, and will continue to decrease between the present day and 2050, to 2.3 persons (Figure 4).

Table 3. Distribution of household numbers, according to the extrapolative headship rate method, 2020-2050.

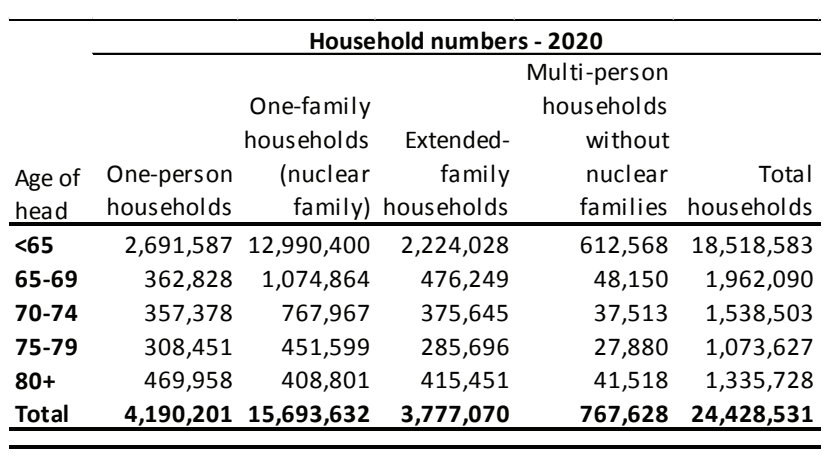

\begin{tabular}{|c|c|c|c|c|c|}
\hline \multirow[b]{2}{*}{$\begin{array}{l}\text { Age of } \\
\text { head }\end{array}$} & \multicolumn{5}{|c|}{ Household numbers - 2030} \\
\hline & $\begin{array}{l}\text { One-person } \\
\text { households }\end{array}$ & $\begin{array}{r}\text { One-family } \\
\text { households } \\
\text { (nuclear } \\
\text { family) }\end{array}$ & $\begin{array}{r}\text { Extended- } \\
\text { family } \\
\text { households }\end{array}$ & $\begin{array}{r}\text { Multi-person } \\
\text { households } \\
\text { without } \\
\text { nuclear } \\
\text { families }\end{array}$ & $\begin{array}{r}\text { Total } \\
\text { households }\end{array}$ \\
\hline$<65$ & $4,090,924$ & $13,739,667$ & $2,443,788$ & $1,102,566$ & $21,376,945$ \\
\hline 55-69 & 9,503 & $1,563,450$ & 507,394 & 111,097 & 1,444 \\
\hline $0-74$ & & $1,215,686$ & 374,835 & ,049 & \\
\hline 15-79 & & & 353, & 7,793 & 1,842 \\
\hline $30+$ & 849,821 & 630,595 & 441,276 & 83,676 & $2,005,368$ \\
\hline otal & $6,689,895$ & $17,978,398$ & $4,120,981$ & $1,446,181$ & $30,235,455$ \\
\hline
\end{tabular}

\begin{tabular}{|c|c|c|c|c|c|}
\hline \multirow{6}{*}{$\begin{array}{l}\text { Age of } \\
\text { head }\end{array}$} & \multicolumn{5}{|c|}{ Household numbers - 2040} \\
\hline & \multirow{5}{*}{$\begin{array}{l}\text { One-person } \\
\text { households }\end{array}$} & \multirow{5}{*}{$\begin{array}{r}\text { One-family } \\
\text { households } \\
\text { (nuclear } \\
\text { family) }\end{array}$} & \multicolumn{3}{|c|}{ Multi-person } \\
\hline & & & & households & \\
\hline & & & Extended- & without & \\
\hline & & & family & nuclear & Total \\
\hline & & & households & families & households \\
\hline$<65$ & $5,467,857$ & $13,889,947$ & $2,578,212$ & $1,606,809$ & $23,542,825$ \\
\hline $65-69$ & 790,401 & $1,914,014$ & 455,938 & 182,309 & $3,342,662$ \\
\hline $70-74$ & 777,193 & $1,652,371$ & 326,728 & 134,592 & $2,890,884$ \\
\hline 75-79 & 948,761 & $1,283,466$ & 373,264 & 126,873 & $2,732,364$ \\
\hline $80+$ & $1,587,965$ & $1,058,601$ & 512,054 & 169,906 & $3,328,526$ \\
\hline \multirow[t]{5}{*}{ Total } & $9,572,177$ & $19,798,398$ & $4,246,197$ & $2,220,489$ & $35,837,261$ \\
\hline & \multicolumn{5}{|c|}{ Household numbers - 2050} \\
\hline & \multirow{5}{*}{\multicolumn{2}{|c|}{$\begin{array}{cr}\begin{array}{r}\text { One-family } \\
\text { households }\end{array} \\
\text { One-person } \quad \text { (nuclear } \\
\text { households } \quad \text { family) h }\end{array}$}} & \multirow{2}{*}{\multicolumn{3}{|c|}{$\begin{array}{r}\text { Multi-person } \\
\text { households }\end{array}$}} \\
\hline & & & & & \\
\hline & & & Extended- & without & \\
\hline Age of & & & family & nuclear & Total \\
\hline head & & & households & families & households \\
\hline$<65$ & $6,497,626$ & $13,189,518$ & $2,506,391$ & $2,023,735$ & $24,217,270$ \\
\hline $65-69$ & $1,025,430$ & $2,300,606$ & 403,032 & 270,623 & $3,999,691$ \\
\hline 70-74 & $1,163,549$ & $2,451,319$ & 315,011 & 230,840 & $4,160,719$ \\
\hline 75-79 & $1,261,554$ & $1,659,012$ & 331,772 & 188,691 & $3,441,028$ \\
\hline $80+$ & $2,535,583$ & $1,568,466$ & 526,214 & 291,003 & $4,921,266$ \\
\hline Total & $12,483,741$ & $21,168,922$ & $4,082,420$ & $3,004,892$ & $40,739,975$ \\
\hline
\end{tabular}

\begin{tabular}{|c|c|c|c|c|c|}
\hline \multirow[b]{2}{*}{$\begin{array}{l}\text { Age of } \\
\text { head }\end{array}$} & \multicolumn{5}{|c|}{ Household numbers - 2025} \\
\hline & $\begin{array}{l}\text { One-person } \\
\text { households }\end{array}$ & $\begin{array}{r}\text { One-family } \\
\text { households } \\
\text { (nuclear } \\
\text { family) }\end{array}$ & $\begin{array}{r}\text { Extended- } \\
\text { family } \\
\text { households }\end{array}$ & $\begin{array}{r}\text { Multi-person } \\
\text { households } \\
\text { without } \\
\text { nuclear } \\
\text { families }\end{array}$ & $\begin{array}{r}\text { Total } \\
\text { households }\end{array}$ \\
\hline$<65$ & $3,403,527$ & $13,509,359$ & $2,380,614$ & 853,535 & $20,147,035$ \\
\hline 65-69 & 436,129 & $1,218,966$ & 462,107 & 70,950 & $2,188,152$ \\
\hline $70-74$ & 481,267 & $1,032,784$ & 400,100 & 60,129 & $1,974,279$ \\
\hline $75-79$ & 433,133 & 619,416 & 321,327 & 44,715 & $1,418,591$ \\
\hline $80+$ & 606,437 & 483,198 & 407,274 & 56,816 & $1,553,725$ \\
\hline \multirow[t]{3}{*}{ Total } & $5,360,494$ & $16,863,724$ & $3,971,421$ & $1,086,144$ & $27,281,782$ \\
\hline & \multicolumn{5}{|c|}{ Household numbers - 2035} \\
\hline & $\begin{array}{l}\text { One-person } \\
\text { households }\end{array}$ & $\begin{array}{r}\text { One-family } \\
\text { households } \\
\text { (nuclear } \\
\text { family) }\end{array}$ & $\begin{array}{r}\text { Extended- } \\
\text { family } \\
\text { households }\end{array}$ & $\begin{array}{r}\text { Multi-person } \\
\text { households } \\
\text { without } \\
\text { nuclear } \\
\text { families }\end{array}$ & $\begin{array}{r}\text { Total } \\
\text { households } \\
\end{array}$ \\
\hline$<65$ & $4,826,620$ & $13,976,732$ & $2,549,944$ & $1,363,588$ & $22,716,885$ \\
\hline 65-69 & 613,610 & $1,551,786$ & 431,353 & 129,412 & $2,726,162$ \\
\hline $70-74$ & 756,778 & $1,615,103$ & 398,047 & 120,115 & $2,890,043$ \\
\hline $75-79$ & 704,176 & 968,413 & 340,713 & 87,767 & $2,101,069$ \\
\hline $80+$ & $1,211,491$ & 847,856 & 493,057 & 124,614 & $2,677,018$ \\
\hline \multirow[t]{3}{*}{ Total } & $8,112,676$ & $18,959,890$ & $4,213,115$ & $1,825,495$ & $33,111,176$ \\
\hline & \multicolumn{5}{|c|}{ Household numbers - 2045} \\
\hline & $\begin{array}{l}\text { One-person } \\
\text { households }\end{array}$ & $\begin{array}{r}\text { One-family } \\
\text { households } \\
\text { (nuclear } \\
\text { family) }\end{array}$ & $\begin{array}{r}\text { Extended- } \\
\text { family } \\
\text { households }\end{array}$ & $\begin{array}{r}\text { Multi-person } \\
\text { households } \\
\text { without } \\
\text { nuclear } \\
\text { families }\end{array}$ & $\begin{array}{r}\text { Total } \\
\text { households }\end{array}$ \\
\hline$<65$ & $6,011,638$ & $13,574,556$ & $2,551,425$ & $1,823,860$ & $23,961,478$ \\
\hline 65-69 & 936,566 & $2,179,558$ & 445,141 & 232,454 & $3,793,719$ \\
\hline 70-74 & 990,309 & $2,096,350$ & 333,677 & 184,534 & $3,604,870$ \\
\hline $75-79$ & 981,980 & $1,308,841$ & 315,332 & 139,432 & $2,745,585$ \\
\hline $80+$ & $2,137,208$ & $1,367,988$ & 550,863 & 237,119 & $4,293,177$ \\
\hline Total & $11,057,701$ & $20,527,292$ & $4,196,438$ & $2,617,399$ & $38,398,829$ \\
\hline
\end{tabular}




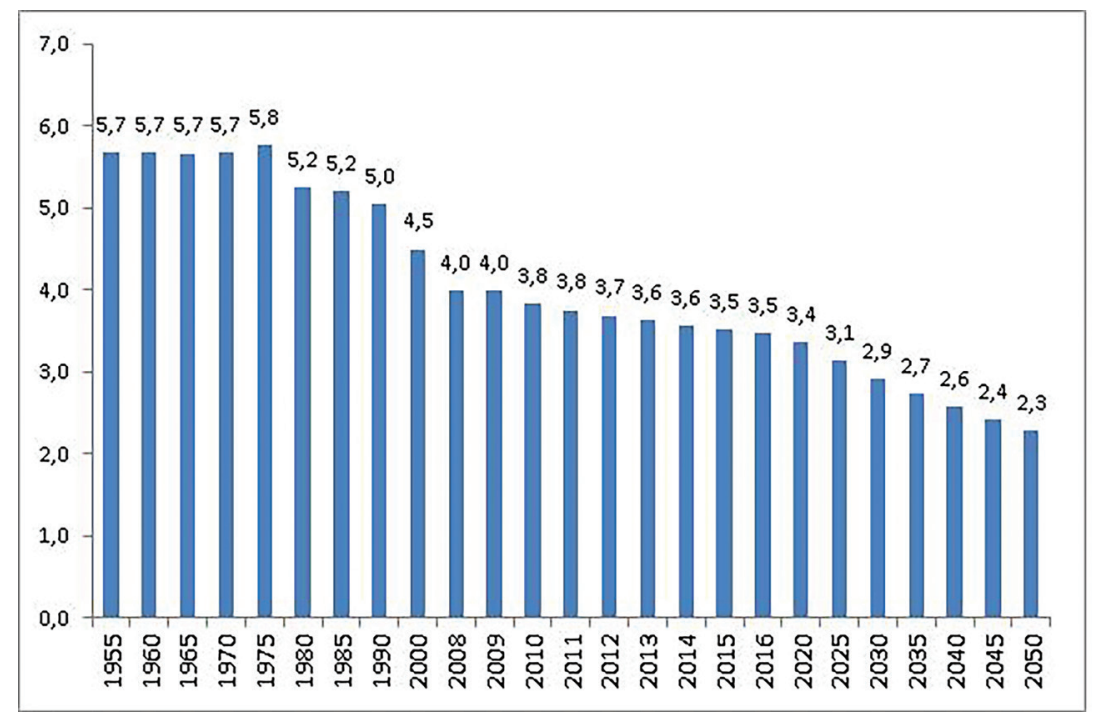

Figure 4. Changes in average household size in Turkey, by total population.

\section{DISCUSSION}

In this study, the living arrangements of elderly persons in Turkey have been investigated for the first time, using ABPRS tabulated data. As mentioned in introduction section, main purpose of this study to produce household projection for old people for the first time by using statistics from administrative registers in Turkey in order to raise awareness to living arrangements that is one of the key issues of elderly. It is obvious that there are strong effects of gender, educational level, regional difference, urbanization, religion and financial power of elderly on their living arrangements. There are many studies that include sociological and demographic models in order to examine the effects of these variables on living arrangements. While these studies have maintained their validity even though they were done in the beginning of 2000s, they didn't include any information about long term projection and change in household types. In the light of this study, alternative household projections can be produced in the future according to educational level, gender or urban-rural residential status of the reference person.
In the majority of developing countries, like Turkey, family members are trusted to meet the needs of and care for the elderly. However, families in Turkey are changing; traditional, complex family structures are eroding, and the average household size is decreasing. Changes that occur in the population dynamics affect the family and household structures in the society. The most common household type in Turkey is the one-family (nuclear) household. This study shows that while nuclear households are still common, they will be less common future than they are today, and oneperson households will show a significant increase compared with the other household types. The results of this study are compatible with those of other studies that have used DHS data and census records (14-20).

In 2016, one of every five households in Turkey included at least one elderly person. This number will be two of every five households in 2050. The elderly will mostly live in one-family households in the future, as is the case at present, and there will be an increase in the number of elderly persons living in one-person households. Moreover, about $15 \%$ of households in Turkey will be one-person 
elderly households in 2050. It is expected that a significant number of this households will comprise females. This study's argument is justified by related observations and field studies (18-20).

Theoretically, the composition of households in a country is similar to the size of the households in that country. According to the results of this study, the increase in single-person households and multihomeless households with no nuclear family, and the decrease in the number of nuclear families and large family households, seem to be consistent with the declines in fertility and average household size in Turkey. In a study carried out by Bongaarts (21), it was determined that countries with relatively older populations tend to have smaller household structures. The decrease that has taken place in respect to fertility in industrialized countries in the $20^{\text {th }}$ century is the main driving force behind the decrease that has taken place in average household sizes in Europe and North America. According to the author (21), the second reason for the decrease in household size is the decrease in the number of adults per household. It is stated that this decrease reflects the transition from the traditional, very complex household structure to the simpler, nuclear household structure in contemporary industrialized communities. The results of this study also show that the same situation is observable in Turkey and that despite continuous increases in both the number of households and people in Turkey, the average household size will decrease.

According to convergence theory, households tend to be less extended, more nuclear, and of smaller average sizes, as societies are industrialized and urbanization rates are increasing. Goode (22) foresaw the convergence of family systems around the world to be the conjugal type: "Wherever the economic system expands through industrialization family patterns change. Extended kinship ties weaken, lineage patterns dissolve, and a trend toward some form of the conjugal system generally begins to appear - that is, nuclear family becomes a more independent kinship unit." According to Goode, the most important indicator of this transition is the weakening of ties with older generations. In commenting on the "weakening of the ties", Goode is referring to the lack of support for the elderly financially and physically, their lack of social interaction, and their increasing tendency to live separately. The same trend was also experienced during the industrialization process of European and North American societies. During the 150-year period 1850-2000, the average household size was dropped from 4 to 6 members to 2 to 3 members $(21,22)$. In those countries, the nuclear family household type is now dominant. Demographic indicators show that the population in Turkey has also entered into this phase of aging. This study has projected the aged population structure after 2030, and its findings relating to the changes in household structures during that time and smaller household sizes are compatible with the results of the abovementioned study and convergence theory.

In light of the findings of this study, it can be concluded that the elderly in Turkey will steadily move from co-residence lifestyles to single-resident lifestyles and that this transition tends to take away family support in the long-term care of the aging family member (23). In addition, long-term care needs and services are wide-ranging and complex. Under these conditions, the traditional methods that were employed to meet the needs of elderly family members will be insufficient, and the public services provided to this group in Turkey will be increasingly important and in need of intensification. In addition to these, as stated in the $10^{\text {th }}$ Development Plan of Turkey, an effective home care system must be encouraged and supported. There is higher representation of older women in Turkey who are more dependent to another individual and institution from social, economic, cultural and legal point of views (24). In this context, variables such as gender and marital status that will cause fragility should also be taken into account in the policies of elderly care. 
Annex 1. Headship rates according to the extrapolative method of the household headship rates.

\begin{tabular}{|c|c|c|c|c|c|c|c|c|c|}
\hline \multirow[b]{2}{*}{$\begin{array}{l}\text { Age of } \\
\text { head }\end{array}$} & \multicolumn{4}{|c|}{ Household headship rates of 2020} & & \multicolumn{4}{|c|}{ Household headship rates of 2025} \\
\hline & $\begin{array}{l}\text { One-person } \\
\text { households }\end{array}$ & $\begin{array}{r}\text { One-family } \\
\text { households } \\
\text { (nuclear } \\
\text { family) }\end{array}$ & $\begin{array}{r}\text { Extended- } \\
\text { family } \\
\text { households }\end{array}$ & $\begin{array}{r}\text { Multi-person } \\
\text { households } \\
\text { without } \\
\text { nuclear } \\
\text { families } \\
\end{array}$ & $\begin{array}{l}\text { Age of } \\
\text { head }\end{array}$ & $\begin{array}{l}\text { One-person } \\
\text { households }\end{array}$ & $\begin{array}{r}\text { One-family } \\
\text { households } \\
\text { (nuclear } \\
\text { family) }\end{array}$ & $\begin{array}{r}\text { Extended- } \\
\text { family } \\
\text { households }\end{array}$ & $\begin{array}{r}\text { Multi-person } \\
\text { households } \\
\text { without } \\
\text { nuclear } \\
\text { families } \\
\end{array}$ \\
\hline 15-19 & 0.0024 & 0.0007 & 0.0000 & 0.0004 & $15-19$ & 0.0010 & 0.0009 & 0.0000 & 0.0001 \\
\hline $20-24$ & 0.0444 & 0.0242 & 0.0010 & 0.0086 & $20-24$ & 0.0517 & 0.0285 & 0.0013 & 0.0089 \\
\hline $25-29$ & 0.0642 & 0.1283 & 0.0075 & 0.0152 & $25-29$ & 0.0790 & 0.1344 & 0.0084 & 0.0180 \\
\hline 30-34 & 0.0514 & 0.2312 & 0.0175 & 0.0142 & 30-34 & 0.0642 & 0.2207 & 0.0188 & 0.0191 \\
\hline 35-39 & 0.0438 & 0.2932 & 0.0318 & 0.0115 & 35-39 & 0.0533 & 0.2684 & 0.0382 & 0.0159 \\
\hline 40-44 & 0.0448 & 0.3457 & 0.0433 & 0.0116 & 40-44 & 0.0564 & 0.3265 & 0.0520 & 0.0167 \\
\hline $45-49$ & 0.0493 & 0.3734 & 0.0529 & 0.0125 & $45-49$ & 0.0618 & 0.3632 & 0.0552 & 0.0182 \\
\hline $50-54$ & 0.0542 & 0.3713 & 0.0779 & 0.0119 & $50-54$ & 0.0653 & 0.3663 & 0.0706 & 0.0167 \\
\hline $55-59$ & 0.0710 & 0.3699 & 0.1042 & 0.0140 & $55-59$ & 0.0838 & 0.3729 & 0.0875 & 0.0198 \\
\hline $60-64$ & 0.0895 & 0.3582 & 0.1389 & 0.0138 & $60-64$ & 0.0999 & 0.3556 & 0.1223 & 0.0184 \\
\hline 65-69 & 0.1230 & 0.3645 & 0.1615 & 0.0163 & 65-69 & 0.1329 & 0.3715 & 0.1408 & 0.0216 \\
\hline $70-74$ & 0.1708 & 0.3670 & 0.1795 & 0.0179 & 70-74 & 0.1811 & 0.3887 & 0.1506 & 0.0226 \\
\hline 75-79 & 0.2315 & 0.3390 & 0.2145 & 0.0209 & $75-79$ & 0.2480 & 0.3547 & 0.1840 & 0.0256 \\
\hline \multirow[t]{3}{*}{$80+$} & 0.3198 & 0.2781 & 0.2827 & 0.0282 & $80+$ & 0.3588 & 0.2859 & 0.2410 & 0.0336 \\
\hline & \multicolumn{4}{|c|}{ Household headship rates of 2030} & & \multicolumn{4}{|c|}{ Household headship rates of 2035} \\
\hline & $\begin{array}{l}\text { One-person } \\
\text { households }\end{array}$ & $\begin{array}{r}\text { One-family } \\
\text { households } \\
\text { (nuclear } \\
\text { family) }\end{array}$ & $\begin{array}{r}\text { Extended- } \\
\text { family } \\
\text { households }\end{array}$ & $\begin{array}{r}\text { Uulti-person } \\
\text { households } \\
\text { without } \\
\text { nuclear } \\
\text { families } \\
\end{array}$ & $\begin{array}{l}\text { Age of } \\
\text { head }\end{array}$ & $\begin{array}{l}\text { One-person } \\
\text { households }\end{array}$ & $\begin{array}{r}\text { One-family } \\
\text { households } \\
\text { (nuclear } \\
\text { family) }\end{array}$ & $\begin{array}{r}\text { Extended- } \\
\text { family } \\
\text { households } \\
\end{array}$ & $\begin{array}{r}\text { Multi-person } \\
\text { households } \\
\text { without } \\
\text { nuclear } \\
\text { families } \\
\end{array}$ \\
\hline $15-19$ & 0.0004 & 0.0010 & 0.0000 & 0.0000 & $15-19$ & 0.0002 & 0.0012 & 0.0000 & 0.0000 \\
\hline $20-24$ & 0.0588 & 0.0328 & 0.0016 & 0.0092 & $20-24$ & 0.0660 & 0.0371 & 0.0019 & 0.0095 \\
\hline $25-29$ & 0.0937 & 0.1406 & 0.0093 & 0.0207 & $25-29$ & 0.1081 & 0.1467 & 0.0102 & 0.0234 \\
\hline 30-34 & 0.0769 & 0.2107 & 0.0201 & 0.0239 & $30-34$ & 0.0895 & 0.2012 & 0.0214 & 0.0288 \\
\hline $35-39$ & 0.0628 & 0.2456 & 0.0445 & 0.0202 & $35-39$ & 0.0721 & 0.2248 & 0.0508 & 0.0244 \\
\hline 40-44 & 0.0679 & 0.3083 & 0.0607 & 0.0218 & $40-44$ & 0.0792 & 0.2912 & 0.0693 & 0.0269 \\
\hline $45-49$ & 0.0741 & 0.3533 & 0.0575 & 0.0239 & $45-49$ & 0.0863 & 0.3437 & 0.0598 & 0.0296 \\
\hline $50-54$ & 0.0763 & 0.3614 & 0.0639 & 0.0214 & $50-54$ & 0.0872 & 0.3566 & 0.0578 & 0.0262 \\
\hline $55-59$ & 0.0965 & 0.3758 & 0.0735 & 0.0256 & $55-59$ & 0.1090 & 0.3788 & 0.0617 & 0.0313 \\
\hline $60-64$ & 0.1102 & 0.3530 & 0.1077 & 0.0230 & $60-64$ & 0.1203 & 0.3504 & 0.0948 & 0.0275 \\
\hline $65-69$ & 0.1427 & 0.3784 & 0.1228 & 0.0269 & $65-69$ & 0.1523 & 0.3852 & 0.1071 & 0.0321 \\
\hline 70-74 & 0.1913 & 0.4096 & 0.1263 & 0.0273 & 70-74 & 0.2014 & 0.4298 & 0.1059 & 0.0320 \\
\hline 75-79 & 0.2642 & 0.3700 & 0.1579 & 0.0303 & $75-79$ & 0.2800 & 0.3850 & 0.1355 & 0.0349 \\
\hline \multirow[t]{2}{*}{$80+$} & 0.3957 & 0.2936 & 0.2055 & 0.0390 & $80+$ & 0.4304 & 0.3012 & 0.1752 & 0.0443 \\
\hline & \multicolumn{4}{|c|}{ Household headship rates of 2040} & & \multicolumn{4}{|c|}{ Household headship rates of 2045} \\
\hline $\begin{array}{l}\text { Age of } \\
\text { head }\end{array}$ & $\begin{array}{l}\text { One-person } \\
\text { households }\end{array}$ & $\begin{array}{r}\text { One-family } \\
\text { households } \\
\text { (nuclear } \\
\text { family) }\end{array}$ & $\begin{array}{r}\text { Extended- } \\
\text { family } \\
\text { households }\end{array}$ & $\begin{array}{r}\text { hulti-person } \\
\text { households } \\
\text { without } \\
\text { nuclear } \\
\text { families } \\
\end{array}$ & $\begin{array}{l}\text { Age of } \\
\text { head }\end{array}$ & $\begin{array}{l}\text { One-person } \\
\text { households }\end{array}$ & $\begin{array}{r}\text { One-family } \\
\text { households } \\
\text { (nuclear } \\
\text { family) }\end{array}$ & $\begin{array}{r}\text { Extended- } \\
\text { family } \\
\text { households } \\
\end{array}$ & $\begin{array}{r}\text { Multi-person } \\
\text { households } \\
\text { without } \\
\text { nuclear } \\
\text { families } \\
\end{array}$ \\
\hline 15-19 & 0.0001 & 0.0013 & 0.0000 & 0.0000 & 15-19 & 0.0000 & 0.0014 & 0.0000 & 0.0000 \\
\hline $20-24$ & 0.0731 & 0.0413 & 0.0022 & 0.0098 & $20-24$ & 0.0801 & 0.0456 & 0.0025 & 0.0101 \\
\hline $25-29$ & 0.1222 & 0.1528 & 0.0111 & 0.0261 & $25-29$ & 0.1362 & 0.1588 & 0.0120 & 0.0288 \\
\hline 30-34 & 0.1018 & 0.1921 & 0.0227 & 0.0336 & 30-34 & 0.1140 & 0.1834 & 0.0240 & 0.0384 \\
\hline 35-39 & 0.0814 & 0.2057 & 0.0570 & 0.0287 & 35-39 & 0.0905 & 0.1883 & 0.0632 & 0.0330 \\
\hline 40-44 & 0.0904 & 0.2750 & 0.0778 & 0.0319 & 40-44 & 0.1014 & 0.2597 & 0.0862 & 0.0369 \\
\hline $45-49$ & 0.0983 & 0.3343 & 0.0620 & 0.0352 & $45-49$ & 0.1101 & 0.3252 & 0.0643 & 0.0408 \\
\hline 50-54 & 0.0980 & 0.3518 & 0.0524 & 0.0309 & $50-54$ & 0.1086 & 0.3471 & 0.0474 & 0.0356 \\
\hline $55-59$ & 0.1213 & 0.3817 & 0.0518 & 0.0370 & $55-59$ & 0.1335 & 0.3846 & 0.0435 & 0.0426 \\
\hline $60-64$ & 0.1304 & 0.3478 & 0.0835 & 0.0321 & $60-64$ & 0.1403 & 0.3453 & 0.0736 & 0.0366 \\
\hline $65-69$ & 0.1619 & 0.3919 & 0.0934 & 0.0373 & $65-69$ & 0.1713 & 0.3986 & 0.0814 & 0.0425 \\
\hline 70-74 & 0.2113 & 0.4493 & 0.0888 & 0.0366 & 70-74 & 0.2211 & 0.4681 & 0.0745 & 0.0412 \\
\hline $75-79$ & 0.2954 & 0.3996 & 0.1162 & 0.0395 & $75-79$ & 0.3105 & 0.4139 & 0.0997 & 0.0441 \\
\hline \multirow[t]{3}{*}{$80+$} & 0.4631 & 0.3087 & 0.1493 & 0.0496 & $80+$ & 0.4940 & 0.3162 & 0.1273 & 0.0548 \\
\hline & Hous & sehold heads & hip rates of 2 & & & & & & \\
\hline & $\begin{array}{l}\text { One-person } \\
\text { households }\end{array}$ & $\begin{array}{r}\text { One-family } \\
\text { households } \\
\text { (nuclear } \\
\text { family) }\end{array}$ & $\begin{array}{r}\text { Extended- } \\
\text { family } \\
\text { households }\end{array}$ & $\begin{array}{r}\text { Uulti-person } \\
\text { households } \\
\text { without } \\
\text { nuclear } \\
\text { families } \\
\end{array}$ & & & & & \\
\hline $15-19$ & 0.0000 & 0.0016 & 0.0000 & 0.0000 & & & & & \\
\hline $20-24$ & 0.0870 & 0.0498 & 0.0028 & 0.0104 & & & & & \\
\hline $25-29$ & 0.1499 & 0.1648 & 0.0129 & 0.0315 & & & & & \\
\hline $30-34$ & 0.1261 & 0.1750 & 0.0253 & 0.0431 & & & & & \\
\hline $35-39$ & 0.0996 & 0.1723 & 0.0694 & 0.0372 & & & & & \\
\hline $40-44$ & 0.1124 & 0.2453 & 0.0945 & 0.0419 & & & & & \\
\hline $45-49$ & 0.1218 & 0.3163 & 0.0666 & 0.0464 & & & & & \\
\hline $50-54$ & 0.1191 & 0.3425 & 0.0429 & 0.0402 & & & & & \\
\hline 55-59 & 0.1454 & 0.3875 & 0.0365 & 0.0483 & & & & & \\
\hline $60-64$ & 0.1502 & 0.3427 & 0.0648 & 0.0411 & & & & & \\
\hline $65-69$ & 0.1806 & 0.4052 & 0.0710 & 0.0477 & & & & & \\
\hline 70-74 & 0.2308 & 0.4863 & 0.0625 & 0.0458 & & & & & \\
\hline 75-79 & 0.3253 & 0.4278 & 0.0856 & 0.0487 & & & & & \\
\hline $80+$ & 0.5231 & 0.3236 & 0.1086 & 0.0600 & & & & & \\
\hline
\end{tabular}




\section{REFERENCES}

1. Turkish Statistical Institute. Eldery Statistics, 2017. [Internet] Available from: http://www. turkstat.gov.tr/PreHaberBultenleri.do?id=27595. Accessed:15.03.2018.

2. Kramarow EA. The elderly who live alone in theUnitedStates:historicalperspectivesonhousehold change. Demography 1995 Aug;32(3):335-52. (PMID:8829970).

3. Palloni A. Living arrangements of older persons, In: United Nations Living arrangements of older persons: Critical issues and policy responses. Population Bulletin of the United Nations, Special Issue Nos. 42/43, United Nations, New York 2001, pp 54-110. [Internet] Available from: http://www. un.org/esa/population/publications/bulletin42_43/ palloni.pdf. Accessed:11.12.2016.

4. Aytaç IA. Intergenerational living arrangements in Turkey. Journal of Cross-Cultural Gerontology 1998; 13:241-64.

5. Aykan H, Wolf DA. Traditionality, modernity, and household composition: Parent-child coresidence in contemporary Turkey. Research on Aging 2000;22(4):95-42.

6. İçli G. Elderly people and adults. Elderly Issues Research Journal/Yaşlı Sorunları Araştırma Dergisi 2008(1):29-38. [Internet] Available from: http://dergipark.ulakbim.gov.tr/yasad/article/ view/5000115883. Accessed: 16.3.2018.

7. Turkish Statistical Institute. Elderly Statistics, 2016. [Internet] Available from: http://www. turkstat.gov.tr/PreHaberBultenleri.do?id=24644. Accessed:16.03.2018.

8. Sarripek DA. Demographic shift and elderly care in Turkey. SGD Journal of Social Security 2016 Oct; 6(2):93-112. [Internet] Available from: http:// dergipark.gov.tr/download/article-file/297671. Accessed: 16.3.2018.

9. Bulletin of Statistical Information on Elderly and Disabled People, January 2018. Republic of Turkey Ministry of Family and Social Policies, General Directorate of Services for Disabled and Elderly "online" publications. [Internet] Available from: http://eyh.aile.gov.tr/ data/551169ab369dc57100ffbf13/B\%C3\%BCltenOcak2018(son).pdf. Accessed:15.03.2018. (in Turkish).
10. Keilman N. Dynamic household models, In: Keilman, Kuijsten and Vossen (Eds). Modelling Household Formation and Dissolution. Clarendon Press of Oxford University Press, Oxford, 1988, pp 123-38.

11. Kono $\mathrm{S}$. The headship rate method for projecting households, In: John Bongaarts, Thomas K. Burch, Kenneth W. Wachter (Eds). Family Demography. Clarendon Press of Oxford University Press, Oxford, 1987, pp 287-308.

12. Linke $W$. The headship rate approach in modelling households: The case of the Federal Republic of Germany, In:Nico Keilman, Anton Kuijsten, Ad Vossen (Eds). Modelling Household Formation and Dissolution. Clarendon Press of Oxford University Press, Oxford, 1988, pp 108-22.

13. United Nations. Manual VII Methods of Projecting Households and Families. Department of Economic and Social Affairs, Population Studies, No. 54, New York, 1973, pp 31-40. [Internet] Available from: http:// www.un.org/esa/population/techcoop/Soclnd/ manual7/chapter4.pdf. Accessed:13.12.2017.

14. Ünalan T. Changing family structure in Turkey, 1968-1998, In: Tuljapurkar, Shripad, Pool, Ian, Prachuabmoh, Vipan (Eds.). Population, Resources and Development, International Studies in Population, Riding The Age Waves, Volume 1, Part III, The Netherlands, Springer, 2005 pp 181-201.

15. Kunt G. Family structure and fertility, In: Population Structure and Population Issues in Turkey. Hacettepe University Publications D-25, Ankara 1978, pp 13346. (in Turkish).

16. Hancıoğlu A. Family types and household types in Turkey. The Turkish Journal of Population Studies/ Hacettepe University Institute of Population Studies 1985;7:61-76

17. Özbay F. Family and Household Structure in Turkey: Yesterday, Today, and Tomorrow. In: Hacımirzaoğlu (Eds). Women and Men in 75 Years - Balance-sheet 98. İş Bankası Press, İstanbul, 1998, pp 155-172. (in Turkish).

18. Koç i. The timing of leaving parental home and its relationship with other life course events in Turkey. Marriage and Family Review 2007;42(1):15-22.

19. Ünalan T. The status of the old age population in Turkey. The Turkish Journal of Population Studies/ Hacettepe University Institute of Population Studies 2000;22(1):25-35. 
20. Koç I, Özgören A, Şirin H. Quality of Life among Elderly in Turkey and the Impact of Family Structure (Chapter 7). In: Fertility, Reproductive Health and Ageing in Turkey. HUIPS, Ministry of Health, SPO and TUBITAK, Ankara, ISBN 978-975-491-290-6, 2010, pp 231-83. [Internet] Available from: http://www.hips. hacettepe.edu.tr/turkiyede_dogurganlik_ureme_ sagligi_yaslilik_160910.pdf . Accessed:08.09.2017. (in Turkish).

21. Bongaarts J. Household size and composition in the developing world. Population Council 2001, Working Paper No 144. [Internet] Available from: $\quad$ https://pdfs.semanticscholar.org/f3d9/ 07bdc2a5018d9f508cc48fa1ee9974cc74fa.pdf. Accessed:08.09.2017.
22. Cherlin AJ. Goode's world revolution and family patterns: a reconsideration at fifty years. Population and Development Review 2012;38(4):577-607.

23. Eryurt MA. Elderly Population in Turkey and Preferences for Elderliness, In: Research on Family Structure in Turkey Findings, and Recommendations. T.R. Ministry of Family and Social Policies General Directorate of Family and Community Services, ISBN: 978-605-4628-55-1, Ankara, 2014, pp 90-111. [Internet] Available from: http://ailetoplum.aile.gov. tr/data/54292ce0369dc32358ee2a46/taya2013eng. pdf. Accessed:12.09.2017.

24. Arun Ö. Widowhood: the most salient problem for elderly women in Turkey. Gaziantep University Journal of Social Sciences $2011 ; 10(4): 1515-27$. (in Turkish). 